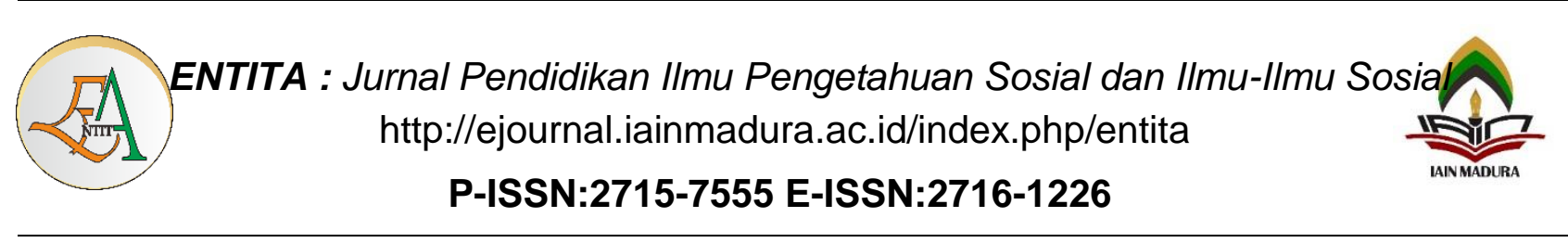

\title{
Pemenuhan Hak Narapidana Disabilitas dalam Memenuhi Kesejahteraan Sosial Kelompok Rentan Di Lembaga Pemasyarakatan
}

\author{
Misbah Ayu Nafarizka \\ Politeknik Ilmu Pemasyarakatan \\ mayunafarizka14@gmail.com \\ Mitro Subroto \\ Politeknik IImu Pemasyarakatan \\ subrotomitro07@gmail.com
}

In providing protection and guaranteeing the rights of persons with disabilities, the Government makes laws and regulations, namely Law Number 8 of 2016. As a human being, of course, persons with disabilities are not free from mistakes, they can also be subject to imprisonment like other citizens. Prisons as a forum for fostering inmates who have been convicted of committing a crime are not entitled to take away the rights they should have. Inmates only lose their freedom of movement and still get human rights. Prisoners with disabilities have different special needs, where this right must be fulfilled by prisons as stated in Law Number 8 of 2016 concerning Persons with Disabilities. The rights they should get can be in the form of special residential rooms, special toilets for disabilities, special disabled lanes, and wheelchairs/canes to facilitate mobility. In its implementation, there are still some obstacles in fulfilling the rights of prisoners with disabilities, therefore this study uses a normative method aimed at examining library materials and secondary materials such as related laws and regulations. The results of the study indicate that the fulfillment of the rights of prisoners with disabilities in prisons is still not optimal, so there is a need for evaluation and quality improvement carried out by prisons and related institutions, besides that further regulations are needed that focus on guaranteeing the rights of prisoners with disabilities. In its implementation, it was found that several prisons had fulfilled the special needs of people with disabilities, but there were still some obstacles in fulfilling the rights of prisoners with disabilities in various prisons, such as the lack of fulfillment such as special toilets for disabilities or even disabled housing rooms, therefore this study uses a normative method aimed at examining library materials and secondary materials such as related laws and regulations. The results of the study indicate that the fulfillment of the rights of prisoners with disabilities in prisons is still not optimal, so there is a need for evaluation and quality improvement carried out by prisons and related institutions, besides that further regulations are needed that focus on guaranteeing the rights of prisoners with disabilities. In its implementation, there are still some obstacles in fulfilling the rights of prisoners with disabilities, therefore this study uses a normative method aimed at examining library materials and secondary materials such as related laws and regulations. The results of the study indicate that the fulfillment of the rights of prisoners with disabilities in prisons is still not optimal, so there is a need for evaluation and quality improvement carried out by prisons and related institutions, besides that further regulations are needed that focus on guaranteeing the rights of prisoners with disabilities.

Keywords:Persons with Disabilities, Prisoners, Rights

Dalam memberikan perlindungan dan menjamin hak-hak penyandang disabilitas, Pemerintah membuat peraturan Perundang-Undangan yaitu UU Nomor 8 Tahun 2016. Sebagai seorang manusia, tentunya penyandang disabilitas tidak luput dari kesalahan, mereka juga dapat dikenakan hukuman pidana penjara selayaknya warga Negara lain. Lapas sebagai wadah 
pembinaan bagi para narapidana yang telah divonis bersalah dalam melakukan tindak pidana tidak berhak merenggut hak yang seharusnya mereka miliki. Narapidana hanya kehilangan kemerdekaan bergerak dan tetap mendapatkan HAM. Narapidana penyandang disabilitas memiliki kebutuhan khusus yang berbeda, dimana hak ini harus dipenuhi oleh Lapas sebagaimana yang tertuang dalam UU Nomor 8 Tahun 2016 tentang Penyandang Disabilitas. Hak yang seharusnya mereka dapatkan bisa berupa kamar hunian khusus, toilet khusus disabilitas, jalur khusus disabilitas, dan kursi roda/tongkat untuk mempermudah mobilitas sebagai wujud memenuhi kesejahteraan sosial kelompok rentan. Dalam implementasinya didapatkan beberapa Lapas sudah memenuhi kebutuhan khusus para penyandang disabilitas, namun masih ditemukan beberapa kendala dalam pemenuhan hak narapidana penyandang disabilitas diberbagai Lapas seperti halnya kurangnya pemenuhan seperti tolet khusus disabilitas atau bahkan kamar hunian disabilitas, karena itu penelitian ini menggunakan metode Normatif yang ditujukan mengkaji dengan meneliti bahan pustaka dan bahan sekunder seperti peraturan perundang-undangan terkait. Hasil penelitian mengatakan bahwa pemenuhan hak narapidana penyandang disabilitas di Lapas masih kurang optimal maka perlunya evaluasi dan peningkatan mutu yang dilakukan oleh Lapas dan instasi terkait, selain itu juga diperlukan peraturan lebih lanjut yang berfokus dalam menjamin hak-hak bagi narapidana penyandang disabilitas.

Kata Kunci: Penyandang Disabilitas, Narapidana, Hak

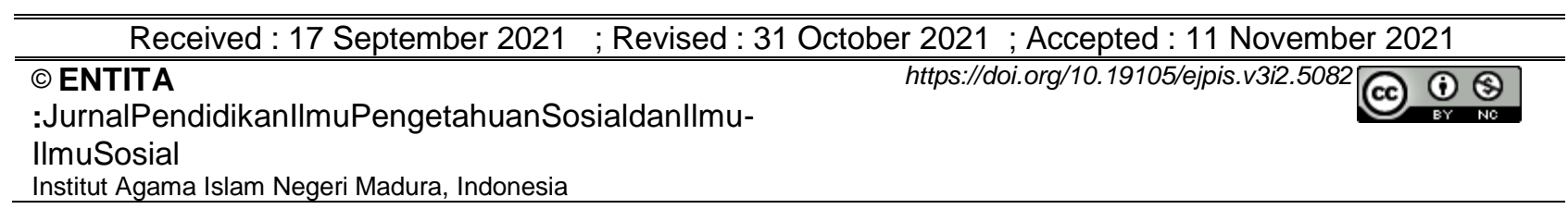

\section{Pendahuluan}

Penyandang Disabilitas merupakan suatu keterbatasan seseorang baik dalam fisik, intelektual, mental, ataupun sensorik sehingga dalam jangka waktu yang lama dan dalam melakukan interaksi dengan lingkungan mengalami kesulitan serta hambatan dalam berpartisipasi secara leluasa dan efektif dengan warga lain berdasarkan kesamaan hak (UU No 8 Tahun 2016, 2016). Menurut Kamus Besar Bahasa Indonesia, penyandang memiliki arti sesuatu yang diderita, sedangkan disabilitas merupakan bahasa Indonesia yang diserap dari bahasa inggris yaitu disability yaitu berarti cacat atau ketidak mampuan. Selanjutnya, menurut John $\mathrm{C}$. Maxwell, penyandang disabilitas adalah seorang yang memiliki suatu kelainan yang mengakibatkan gangguan aktivitas dari orang tersebut (Sugiono et al., 2014). Menurut data yang diolah dari Susenas 2018 dan Riskesdas 2018, penyandang disabilitas di Indonesia dengan kelompok usia 18-59 tahun mempunyai presentase yang cukup menarik perhatian yaitu pada data Susenas 2018 1,75\% dan pada data Riskesdas 2018 $22 \%$ (Dewi et al., 2020). Tentu perbedaan ini didapat karena ada perbedaan pada set pertanyaan yang digunakan untuk mengindetifikasi. Pemerintah Indonesia tentunya telah mengeluarkan Undang- Undang bagi para Penyandang Disabilitas guna memenuhi hakhaknya dalam kegiatannya sehari-hari didalam kehidupan bermasyarakat.

Penyandang disabilitas dikalangan masyarakat kerap dipandang sebelah mata, dianggap sebagai kelompok lemah, seorang yang hanya perlu mendapatkan belas kasihan, 222 
serta hak-hak yang seharusnya tetap mereka dapatkan malah seringkali diabaikan. Hal ini tentunya bertolak belakang dengan sila kedua dari Pancasila yaitu "Kemanusiaan yang adil dan beradab", maka diperlukan peran pemerintah dalam menanggapi persoalan pemenuhan hak bagi para penyandang disabilitas

Dalam hal memberikan perhatian kepada para Penyandang Disabilitas, UndangUndang Republik Indonesia Nomor 8 Tahun 2016 tentang Penyandang Disabilitas dibuat oleh Pemerintah Indonesia untuk melindungi kelangsungan hidup semua warga Negara, termasuk bagi penyandang disabilitas yang tentunya mempunyai kedudukan hukum serta hak asasi manusia yang sama dengan warga Negara lain. Hak Asasi Manusia merupakan salah satu hak yang dimiliki manusia yang dijunjung tinggi serta paling dihormati oleh semua negara di seluruh dunia, termasuk Indonesia(Basri, 2021) .

Tentunya peraturan ini merupakan langkah yang baik bagi pemerintah untuk menyamaratakan hak setiap warga Negara Indonesia, dan dengan dikeluarkannya UU Nomor 8 Tahun 2016 tentang Penyandang Disabilitas ini keberadaan para penyandang disabilitas semakin dilindung, hak-hak yang harusnya mereka dapatkan lebih diterpenuhi, menghilangkan stigma negative bagi para penyandang disabilitas dalam kegiatan bermasyarakat serta mereka mendapatkan akomodasi untuk menjalankan kehidupannya didalam kehidupan bermasyarakat.

Lembaga Pemasyarakatan (LAPAS) merupakan suatu wadah yang berfungsi untuk mendidik dan membimbing para warga negara yang melakukan suatu tindakan pidana yang tentunya sudah divonis sebagai terpidana. Di Indonesia sendiri Lembaga Pemasyarakatan merupakan suatu tahap akhir dalam proses peradilan pidana, dimana apabila terdapat terdakwa yang sudah inkrah dinyatakan bersalah, maka terdakwa wajib ditempatkan didalam Lembaga Pemasyarakatan untuk mendapatkan pembinaandengan tujuan agar tidak mengulangi perbuatan pidana kembali serta menyesali perbuatan yang dilakukan merupakan tindakan yang tidak seharusnya dilakukan, selain itu juga dapat menjadi masyarakat yang mempunyai potensi atau keahlian sehingga menjadi bekal untuk hidup bermasyarakat kembali. Sedangkan menurut KBBI pengertian lembaga yaitu suatu organisasi atau badan yang melakukan suatu usaha atau penyelidikan, dan pemasyarakatan adalah lembaga yang berada dibawah pimpinan Departemen Hukum dan HAM yang berkaitan dengan narapidana, tahanan, bekas terdakwah, atau seorang yang terlibat tindak pidana dihadapan pengadilan untuk kembali kemasyarakat (RAHARJO, 2014). 
Penyandang Disabilitas tentunya mempunyai hak yang sama layaknya seperti warga Negara pada umumnya, termasuk fasilitas-fasilitas yang diperolehtetapi dalam hal ini tidak semua penyandang Disabilitas mampu untuk menggunakan fasilitas yang ada. Dalam hidup bermasyarakat tentunya Penyandang Disabilitas dapat bertindak melanggar hukum atau melakukan suatu tindak pidana serta tentunya diadili layaknya warga Negara lainnya. Fungsi hukum adalah melindungi hak yang dimiliki manusia dalam masyarakat, bangsa, dan Negara(Basri, 2021).Namun pada proses peradilan atas tindak pidana yang telah dilakukan, aparat penegak hukum harus memfasilitasi penyandang disabilitas tersebut dengan fasilitas atau akomodasi khusus agar dapat mempermudah mereka dalam menyelesaikan proses peradilan yang tentunya peraturan ini sudah tertuang dalam Pasal 36 Undang-Undang Republik Indonesia Nomor 8 Tahun 2016.

Undang-Undang Republik Indonesia Nomor 12 Tahun 1995 Tentang Pemasyarakatan dimana dalam hal ini mengatur kegiatan untuk melakukan pembinaan kepada Warga Binaan Pemasyarakatan sebagai rangkaian penegakan hukum yang bertujuan supaya Warga Binaan Pemasyarakatan (WBP) menyadari kesalahannya, memperbaiki diri, tidak melakukan pengulangan tidak pidana, dapat diterima kembali kedalam lingkungan masyarakat, serta dapat melakukan kegiatan yang lebih bermafaat dilingkungannya. Sama hal nya bagi penyandang Disabilitas, didalam Lembaga Pemasyarakatan mereka tentunya harus diperlakukan sama, tidak boleh ada intimidasi atau bahkan dikucilkan oleh para narapidana ataupun petugas Lapas. Tentu Pemasyarakatan harus berperan lebih aktif dalam pemenuhan hak narapidana Penyandang Disabilitas serta tidak berhak membuat mereka lebih buruk dari sebelum dijatuhkan pidana.

Berdasarkan hal tersebut maka pemasyarakatan harus menyediakan pelayanan, pembinaan serta fasilitas yang mampu membantu para narapidana Penyandang Disabilitas adalah sebagai berikut,

1) Blok Khusus bagi narapidana disabilitas, yang mana blok khusus ini diperuntukan kepada Penyandang Disabilitas agar perawatan serta pembinaan kepada mereka lebih terfokus dan mempermudah melakukan hal tersebut.

2) Jalur Khusus penyandang disabilitas, tentu jalur khusus ini dibuat untuk memenuhi narapidana disabilitas dalam melakukan kegiatan didalam Lapas, selain itu jalur ini sangat dibutuhkan oleh para penyandang disabilitas sensorik.

3) Kursi Roda dan Tongkat, guna kursi roda atau tongkat ini untuk mempermudah mobilitas bagi para penyandang Disabilitas didalam Lapas 
4) Toilet Khusus Disabilitas, toilet ini digunakan para narapidana penyandang disabilitas untuk mempermudah kegiatannya yang dimana kondisi disabilitas tersebut tidak dapat menggunakan toilet umum

Pemenuhan fasilitas seperti diatas tentunya sangat dibutuhkan bagi narapidana penyandang disabilitas baik itu pada kegiatan sehari-hari atau bahkan mempermudah mobilitas. Fasilitas tersebut tentu sudah menjadi hak mereka untuk mendapatkannya dan sudah menjadi kewajiban bagi Lembaga Pemasyarakatan khususnya petugas dalam memenuhi hak narapidana penyandang disabilitas tersebut.

Selain dari hak tersebut, tentunya masih banyak hak-hak lain yang harus dipenuhi dan tentunya dibutuhkan oleh para narapidana penyandang disabilitas sesuai dengan kebutuhan tiap-tiap ragam penyandang disabilitas. Negara yang telah merenggut hak kemerdekaan bergeraknya tentu harus bertanggungjawab penuh atas hak hidup yang mereka miliki dan memfasilitasi kebutuhannya selama mereka menjalankan pembinaan didalam Lembaga Pemasyarakatan (Lapas).

Berdasarkan poin diatas, peneliti melakukan penelitian Pemenuhan Hak Narapidana Disabilitas Dalam Memenuhi Kesejahteraan Sosial Kelompok Rentan Di Lembaga Pemasyarakatan, yang mana penelitian ini ditujukan agar dapat menilai apakah Implementasi Pemenuhan Hak Narapidana Penyandang Disabilitas di Lapas sudah sesuai dengan UU Nomor 8 Tahun 2016 tentang Penyandang Disabilitas dan sudah berjalan dengan semestinya atau bahkan sebaliknya dalam hal ini Lembaga Pemasyarakatan kurang memperhatikan atau bahkan tidak memenuhi Hak Narapidana Penyandang Disabilitas.

\section{Metode}

Sifat penelitan ini merupakan penelitian normatif atau penelitian studi kepustakaan. Penelitian ini dilakukan melalui meneliti bahan pustaka / data sekunder(Soekanto, n.d.). Data sekunder yang diambil dari penelitian ini diutamakan kepada peraturan perundangundangan yang berkaitan dengan Penyandang Disabilitas yaitu Undang-Undang Nomor 8 Tahun 2006 dan sistem hukum pemasyarakatan yang menyangkut dengan pemenuhan hak narapidana khususnya narapidana penyandang disabilitas baik pada UU Nomor 12 Tahun 1995 Tentang Pemasyarakatan. Pada penelitian ini data yang didapatkan dari hasil studi pustaka terhadap data sekunder, baik itu bahan hukum primer ataupun bahan hukum sekunder dilakukan analisis dengan menggunakan metode kualitatif. 
Kata kualitatif mempunyai makna bahwa data yang diperoleh, diuraikan secara bermakna dalam bentuk kalimat yang teratur, tertata, logis, tidak tumpang tindih, dan efektif, sehingga hasil analisis yang didapat mudah dipahami (Abdulkadir, 2004). Pada analisis kualitatif, data yang diperoleh lalu disajikan dengan cara deskriptif yang sifatnya dideskripsikan seperti situasi yang sedang dialami, kegiatan, pandangan, atau tentang suatu yang sedang berlangsung, penyimpangan yang sedang muncul, kecenderungan yang tampak, dan pertentangan yang terjadi (Winarno, 1982).

\section{Hasil dan Pembahasan}

\section{Hak Narapidana Berkebutuhan Khusus Berdasarkan UU No. 8 Tahun 2016 tentang Penyandang Disabilitas}

Penyandang Disabilitas merupakan suatu keterbatasan seseorang baik dalam fisik, intelektual, mental, ataupun sensorik sehingga dalam jangka waktu yang lama dan dalam melakukan interaksi dengan lingkungan mengalami kesulitan serta hambatan dalam berpartisipasi secara leluasa dan efektif dengan warga lain berdasarkan kesamaan hak (UU No 8 Tahun 2016, 2016). Menurut Kamus Besar Bahasa Indonesia, penyandang memiliki arti sesuatu yang diderita, sedangkan disabilitas merupakan bahasa Indonesia yang diserap dari bahasa inggris yaitu disability yaitu berarti cacat atau ketidak mampuan. Selanjutnya, menurut John C. Maxwell, penyandang disabilitas adalah seorang yang memiliki suatu kelainan yang mengakibatkan gangguan aktivitas dari orang tersebut (Sugiono et al., 2014).

Berikut merupakan pengertian Penyandang Disabilitas dalam peraturan perundangundangan, yaitu: (Kaukabuddin, 2021)

1. Berdasarkan Resolusi PBB Nomor 61/106 tanggal 13 Desember 2006, Penyandang disabilitas adalah seorang yang tidak dapat menjamin dirinya sendiri, seluruh bahkan sebagian, kebutuhan individual yang normal, dan/atau kehidupan sosial, sebagai hasil dari cacat yang mereka alami, baik yang bersifat bawaan (dari lahir) atau tidak, dalam hal kemampuan fisik dan/atau mentalnya.

2. Menurut Undang-Undang Nomor 39 Tahun 1999 tentang HAM, penyandang disabilitas adalah kelompok masyarakat rentan yang berhak mendapatkan perlakuan dan perlindungan yang lebih berkaitan dengan kekhususannya.

3. Menurut Undang- udang Nomor 11 Tahun 2009 tentang kesejahteraan sosial, penyandang disabilitas meupakan seorang yang tergolong sebagai masyarakat yang memiliki kehidupan yang tidak layak secara kemanusiaan dan memiliki kriteria masalah sosial. 
4. Berdasarkan Undang - Undang Nomor 19 Tahun 2011 tentang Pengesahan Hak- Hak Penyandang disabilitas, penyandang disabilitas adalah orang yang mempunyai hambatan dalam melakukan interaksi dengan lingkungan dan atas sikap masyarakatnya dapat membuat suatu hambatan yang menyulitkan mereka untuk berpartisipasi dalam kesamaan hak akibat dari adanya keterbatasan fisik, mental, intelektual, atau sensorik dalam kurun waktu yang lama.

5. Dalam UU Nomor 8 Tahun 2016 tentang Penyandang Disabilitas, Penyandang disabilitas adalah seseorang yang mempunyai keterbatasan baik dalam fisik, intelektual, mental, dan / atau sensoring dalam kurun waktu lama yang dalam melakukan interaksi dengan lingkungan dapat mengalami suatu hambatan dan kesulitan untuk berpartisipasi secara penuh dan efektif dalam masyarakat berdasarkan kesamaan hak.

Sistem pemasyarakatan adalah suatu sistem dimana narapidana yang telah divonis oleh hakim untuk melakukan pembinaan didalam Lembaga pemasyarakatan (Wulandari, 2012). Dalam menjalankan pembinaan didalam Lembaga Pemasyarakatan, narapidana hanya dirampas kemerdekaan nya sesuai dengan Prinsip Pemasyarakatan yaitu“ Penjatuhan pidana tidak didasari oleh latar belakang pembalasan. Ini berarti tidak boleh terdapat penyiksaan kepada narapidana dan anak didik pada umumnya, baik yang berupa tindakan, perlakuan, ucapan, cara perawatan ataupun penempatan. Satu-satunya derita yang didapatkan oleh narapidana dan anak didik hanya dibatasi kemerdekaannya untuk leluasa bergerak di dalam masyarakat bebas" (pemasyarakatan.com, n.d.). Oleh karena itu Pemerintah khususnya Pemasyarakatan tidak mempunyai hak untuk merenggut hak asasi manusia yang narapidana miliki.

Setiap narapidana yang sedang melakukan pembinaan didalam Lembaga Pemasyarakatan wajib mendapatkan perlakuan yang sama di depan hukum, baik itu narapidana dewasa, narapidana wanita, anak didik, bahkan narapidana kelompok rentan baik itu narapidana lanjut usia, narapidana kelompok teroris atau bahkan narapidana berkebutuhan khusus yaitu penyandang disabilitas. Setiap orang yang tergolong kelompok masyarakat rentan berhak mendapatkan perlakuan dan perlindungan lebih berkenaan dengan kekhususannya (Undang-Undang Republik Indonesia Nomor 39 Tahun 1999 Tentang Hak Asasi Manusia).

Kelompok rentan yaitu suatu kelompok masyarakat yang mempunyai resiko tinggi karena kurangnya kemampuan untuk mempersiapkan diri apabila terdapat ancaman yang beresiko tinggi. Didalam Lembaga Pemasyarakatan, yang termasuk kelompok rentan yaitu 
(Wirawan, 2021) perempuan, anak-anak, lansia, penyandang disabilitas, narapidana dengan putusan seumur hidup, dan narapidana dengan putusan hukuman mati.

Pemerintah Indonesia dalam hal memberikan perlakuan dan jugaperlindungan yang lebih kepadamasyarakat penyandang disabilitas mengambil salah satu langkah dengan membuat penetapan Undang Undang yang mengatur tentang Penyandang Disabilitas yaitu UU Republik Indonesia Nomor 8 Tahun 2016 tentang Penyandang Disabilitas agar dapat menjamin hidup bagi para warga Negara Indonesia penyandang Disabilitas yang mempunyai kedudukan hukum tetap dan hak asasi yang sama dan tak terpisahkan dengan masyarakat lainnya.

Tidak berbeda dengan masyarakat Indonesia pada umumnya, narapidana penyandang disabilitas pun memiliki perlakuan hukum dan Hak Asasi Manusia yang sama dan tentunya tidak berbeda dengan narapidana lainnya. Maka dalam hal ini Lembaga Pemasyarakatan khususnya petugas pemasyarakatan tidak mempunyai hak untuk melakukan tindakan diskriminasi atau membeda-bedakan narapidana penyandang disabilitas dengan narapidana lainnya. Bahkan dalam pemenuhan hak asasi manusia, Pemasyarakatan disini wajib memenuhi kebutuhan-kebutuhan khusus yang seharusnya dimiliki oleh para penyandang disabilitas sesuai dengan kemampuannya.

Maka dengan adanya Undang-Undang Nomor 8 Tahun 2016 ini menjadi suatu peraturan perundang-undangan yang mana guna memanifestasikan persamaan hak dan kesempatan untuk penyandang disabilitas agar mendapatkan hidup yang sejahtera, mandiri dan tidak terjadi diskriminasi. Dalam Peraturan perundang-undangan ini tentunya sudah mengatur baik itu tentang pengertian penyandang disabilitas, ragam disabilitas, hak-hak yang diperoleh oleh penyandang disabilitas, serta pelaksanaan perlindungan serta pemenuhan hak bagi para penyandang disabilitas.

Seperti halnya dalam pada Pasal 2, Pelaksanaan dan pemenuhan hak bagi Penyandang Disabilitas berasaskan :(UU No 8 Tahun 2016, 2016) Penghormatan terhadap martabat, otonomi individu, tanpa diskriminasi, partisipasi penuh, keragaman manusia dan kemanusiaan, kesamaan kesempatan, kesetaraan, aksesibilitas, kapasitas yang terus berkembang dan indentitas anak, inklusif, dan perlakuan khusus dan perlindungan lebih.

Adapun pelaksanaan serta pemenuhan hak ini ditujukan untuk melahirkan penghormatan, pemajuan, perlindungan, dan pemenuhan hak asasi manusia serta kebebasan bagi penyandang disabilitas secara rata, melindungi penyandang disabilitas dari penelantaraan dan eksploitasi, pelecehan atau semua bentuk tindakan diskriminatif, dan tentunya memastikaan pelaksaan usaha penghormatan serta pemenuhan hak penyandang 228 
disabilitas agar mengembangkan diri dan menggunakan seluruh kemampuan diri sesuai dengan bakat atau minat yang mereka miliki untuk dapat berperan dengan optimal pada semua aspek kehidupan berbangsa, bernegara, serta bermasyarakat.

Selain dari asas pelaksanaan serta pemenuhan hak diatas, dalam perundangundangan ini juga mengatur tentang hak penyandang disabilitas yaitu pada Pasal 5 Bab III (UU No 8 Tahun 2016, 2016): hak hidup, hak bebas dari stigma, hak atas privasi, hak atas keadilan dan perlindungan hukum, hak atas pendidikan, hak atas pekerjaan, kewirausahaan dan koperasi, hak atas kesehatan, hak atas politik, hak atas keagamaan, hak atas keolahragaan, hak atas kebudayaan dan pariwisata, hak atas kesejahteraan sosial, hak atas aksesibilitas, hak atas pelayanan publik, hak atas perlindungan dari bencana, hak atas habilitasi dan rehabilitasi, hak atas pendataan, hak atas hidup secara mandiri dan dilibatkan dalam masyarakat, hak atas berekspresi, berkomunikasi, dan memperoleh informasi, hak atas kewarganegaraan, serta hak atas bebas dari disriminasi, penelantaran, penyiksaan, dan eksploitasi.

Hak yang dimiliki oleh penyandang disabilitas berdasarkan Undang-undang diatas tentu merupakan keadaan yang memberikan peluang bagi mereka agar dapat menyalurkan potensi pada segala aspek penyelenggaraan masyarakat dan negara, serta upaya yang diberikan untuk dapat melindungi, mengayomi, serta memperkuat hak penyandang disabilitas.

Tentunya hak penyandang disabilitas ini selaras juga dengan beberapa hak narapidana yang tertuang pada Undang Undang Nomor 12 Tahun 1999 tentang Pemasyarakatan dalam Pasal 14 ayat 1 poin b yaitu "Mendapat perawatan, baik itu perawatan rohani maupun perawatan jasmani" dan poin d "mendapatkan pelayanan kesehatan serta makanan yang layak", serta pada poin e "menyampaikan keluhan".

\section{Upaya Yang Dilakukan Lembaga Pemasyarakatan Dalam Pemenuhan Hak Narapidana Berkebutuhan Khusus Dalam Hal Penyandang Disabilitas}

Pasal 12 menetapkan bahwa pada rangka pembinaan kepada narapidana di Lembaga Pemasyarakatan dilakukan penggolongan atas dasar umur, jenis kelamin, lama pidana yang dijatuhkan, jenis kejahatan serta kriteria lainnya sesuai dengan kebutuhan atau perkembangan pembinaan (Undang-Undang Republik Indonesia, 1995).

Penggolongan ini adalah salah satu upaya yang dilakukan Lembaga Pemasyarakatan untuk mempermudahdalam pemberian hak-hak yang dibutuhkan dan menjamin privasi bagi setiap narapidana. Sebagaimana penggolongan narapidana didalam 
Pasal 12 UU No. 12 Tahun 1995 memang sangat diperlukan baik didalam keamanan maupun pembinaan serta tentunya menghindari dari pengaruh negatif yang mungkin dapat berpengaruh kepada narapidana lain (Abdullah, 2015).

Selain dari penggolongan penempatan bagi narapidana, penyandang disabilitas juga berbeda-beda sesuai dengan ragamnya baik penyandang disabilitas fisik, intelektual, mental, dan sensorik. Diatur pada Pasal 4 Undang-Undang Nomor 8 Tahun 2016, Ragam dari penyandang disabilitas diantaranya :

1. Penyandang disabilitas fisik yaitu seorang yang memliki gangguan dalam fungsi gerak seperti hal nya amputasi, lumpuh, stroke, paraplegi dan orang kecil

2. Penyandang disabilitas interlektual yaitu orang dengan tengganggunya fungsi pikir dikarenakan kecerdasan yang dimiliki dibawah rata-rata seperti halnya down syndrome

3. Penyandang disabiitas mental adalah adanya gangguan fungsi pikir, emosi serta perilaku, antara lain : (Pawestri, 2017)

a. psikososial di antaranya skizofrenia, bipolar, depresi, anxietas, dan gangguan kepribadian;

b. disabilitas perkembangan yang berdampak kepada kemampuan berinteraksi seperti autis dan hiperaktif

4. Penyandang disabilitas sensorik adalah terganggunya salah satu fungsi panca indera yang dimiliki, seperti tuna nerta, tuna rungu, atau tuna wicara.

Dalam Pasal 37 ayat (2) huruf b Lembaga pemasyarakatan wajib memenuhi kebutuhan khusus, contohnya obat-obatan yang diperlukan oleh Penyandang Disabilitas pada saat masa tahanan dan pembinaan (Subarji, 2021). Hal ini tentu selaras dengan Pasal 12 poin e UU No. 8 Tahun 2016 Tentang Penyandang Disabilitas yaitu memperoleh Alat Bantu Kesehatan menurut kebutuhannya.

Pada Pasal 37 ayat (1) (UU No 8 Tahun 2016, 2016)disebutkan “ Rumah tahanan negara dan Lembaga Pemasyarakatan wajib menyajikan Unit Layanan Disabilitas”. Unit layanan disabilitas yang dimaksud dapat berupa :

1. Menyediakan pelayanan untuk masa adaptasi kepada tahanan penyandang disabilitas selama enam bulan

2. Menyediakan kebutuhkan khusus, seperti obat-obatan yang melekat pada penyandang disabilitas dalam masa tahanan dan pembinaan; dan

3. menyediakan layanan rehabilitasi bagi penyandang disabilitas mental

Pada poin satu diatas sudah diterapkan oleh semua Lembaga Pemasyarakatan di Indonesia, dimana apabila terdapat narapidana atau tahanan baru mereka akan 230 
ditempatkan didalam kamar Mapenaling (Masa pengamatan, pengenalan, dan penelitian lapangan) baik itu penyandang disabilitas maupun tidak. Lapas juga menyediakan layanan rehabilitasi untuk penyandang disabilitas mental tetapi sesuai dengan Pasal 38 UndangUndang Republik Indonesia Nomor 8 Tahun 2016: "Pembantaran terhadap Penyandang Disabilitas mentalwajib ditempatkan dalam layanan rumah sakit jiwa ataupusat rehabilitasi”. (UU No 8 Tahun 2016, 2016)

Penyandang disabilitas tentu memiliki suatu kebutuhan dan alat bantu khusus untuk membantu aktivitasnya agar berjalan dengan baik (Pujiono, 2021). Tentunya dalam hal ini Pemasyarakatan sebagai wadah bagi Narapidana menjalankan pembinaan nya harus mendapatkan hak yang layaknya mereka terima sebagai masyarakat pada umumnya. Dalam melakukan upaya memenuhi hak terutama bagi para narapidana penyandang disabilitas, upaya yang dilakukan pemasyarakatan untuk memenuhi unit layanan disabilitas sebagai berikut,

1. Menyediakan blok khusus disabilitas, blok ini berguna untuk menjamin mutu kelangsungan hidup para narapidana penyandang disabilitas, selain itu blok ini juga dapat menjauhkan pengaruh negatif yang dapat mereka terima.

2. Jalur khusus disabilitas, hal ini tentunya sangat bermanfaat bagi para penyandang disabilitas sensorik yaitu narapidana tuna netra. Tentunya jalur khusus disabilitas ini sudah dimiliki oleh banyak Lapas di Indonesia.

3. Kursi roda atau tongkat, klinik lapas tentu sudah memberikan fasilitas ini agar mempermudah jalannya pengobatan atau memberikan kebutuhan ini kepada para penyandang disabilitas. Tetapi kursi roda ini biasanya tidak diberikan secara personal kepada para narapidana, maka dari itu apabila ada narapidana yang sedang membutuhkan kursi roda atau tongkat makaakan langsung diberikan kepada narapidana tersebut.

4. Toilet khusus Disabilitas, guna dari adanya toilet disabilitas ini semata-mata untuk mempermudah penyandang disabilitas dalam melakukan aktivitas.

5. Menjalin kerjasama bersama instansi Pemerintah Pusat dan atau Pemerintah Daerah yang terkait dengan adanya pelayanan kesehatan seperti menjalin kerjasama dengan Dinas kesehatan, Dinas Sosial, atau Rumah Sakit Daerah bahkan dengan Puskesmas.

Untuk memenuhi hak narapidana penyandang disabilitas, perawat Lembaga Pemasyarakatan juga memberikan fasilitas klinik yang setiap hari dapat dikunjungi oleh narapidana yang membutuhkan obat atau membutuhkan pengobatan dan perawatan. 
Memang pada kenyataannya tidak semua Lapas memiliki dokter yang bisa langsung menangani pasien berobat, tetapi bagi Lapas yang masih belum memiliki dokter tentu sudah bekerjasama dengan dokter Puskesmas ataupun Rumas Sakit terdekat. Apabila ada hal yang tidak diinginkan atau ada narapidana yang tidak bisa diatasi oleh perawat Lapas maka pihak Lapas segera membawa narapidana tersebut ke Puskesmas atau Rumas Sakit untuk mendapatkan perawatan intensif yang diperlukan.

Sudah menjadi tugas dari Lembaga Pemasyarakatan diseluruh Indonesia untuk memberikan perhatian yang khusus kepada para narapidana penyandang disabilitas dengan melakukan pembimbingan atau mendidik mereka agar setelah keluar dari Lembaga Pemasyarakatan diharapkan mereka dapat sebagai berikut: (Setiady, 2010)

1. Tidak akan menjadi pelanggar hukumlagi

2. Menjadi anggota masyarakat yangberguna, aktif dan produktif

3. Berbahagia di dunia dan akherat.

\section{Kesimpulan}

Penelitian yang sudah dilakukan, penulis dapat menyimpulkan bahwa Pemenuhan Hak Narapidana Disabilitas Dalam Memenuhi Kesejahteraan Sosial Kelompok Rentan Di Lembaga Pemasyarakatansudah berjalan dengan cukup baik dan sudah cukup selaras dengan yang diharapkan.

Lembaga pemasyarakatan sudah memberikan beberapa fasilitas bagi narapidana penyandang disabilitas seperti halnya:

1. Pemberian kursi roda dan / atau tongkat bagi narapidana penyandang disabilitas sudah berjalan dengan baik, pihak Lembaga Pemasyarakatan khususnya Klinik Lapas memberikan fasilitas kursi roda atau tongkat bagi para narapidana yang membutuhkan khususnya narapidana penyandang disabilitas

2. Jalur disabilitas, hamper di seluruh Lembaga Pemasyarakatan di Indonesia sudah menyediakan jalur disabilitas ini guna untuk mempermudah para narapidana penyandang disabilitas untuk melakukan mobilitas baik itu jalur menuju blok kamar hunian, klinik maupun tempat-tempat lain yang bisa diakses para narapidana.

3. Fasilitas Kesehatan, seperti halnya perawat dan obat-obatan. Didalam Lembaga Pemasyarakatan narapidana penyandang disabilitas maupun narapidana lain diberikan fasilitas yaitu klinik yang tentunya apabila ada narapidana yang membutuhkan perawatan maka dapat mengunjungi klinik dan dapat diperiksa oleh perawat atau diberikan obat yang sesuai dengan keluhan yang dirasakan. 
Tetapi ada suatu kendala yang dihadapi oleh Lapas yaitu beberapa Lapas tidak menyediakan kamar hunian khusus bagi narapidana penyandang disabilitas dan toilet khusus disabilitas, hal ini dikarenakan tidak semua Unit Lembaga Pemasyarakatan memiliki banyak narapidana penyandang disabilitas, oleh karena itu narapidana penyandang disabilitas masih ditempatkan dikamar yang sama seperti narapidana lainnya dan masih menggunakan toilet yang sama seperti narapidana pada umumnya, mengingat juga Lapas di Indonesia banyak mengalami overcrowded maka hal ini masih sangat kurang mendapatkan perhatian.

Dalam mengatasi hal tersebut, pihak Lapas juga tentunya menyediakan kamar perawatan yang diberikan kepada para narapidana yang sedang membutuhkan perawatan lebih, maka apabila ada narapidana yang membutuhkan baik itu narapidana umum dan narapidana penyandang disabilitas tentu kamar itu dapat dipergunakan sebagaimana fungsinya.

\section{Saran}

Dari hasil penelitian yang dilakukan ada beberapa saran yang diberikan untuk mengatasi pemasalahan diatas, diantaranya :

1. Dalam hal pemenuhan Hak narapidana penyandang disabilitas, seharusnya pemerintah membuat suatu peraturan perundang-undangan yang berfokus mengatur tentang pemenuhan hak narapidana penyandang disabiitas didalam Lembaga Pemasyarakatan, sebab pemerintah wajib memberikan perlindungan hukum dan menjamin hak-hak narapidana penyandang disabilitas sebagai warga Negara Indonesia yang tentunya memerlukan kebutuhan khusus sesuai dengan kebutuhan pribadi yang mereka harus dapatkan.

2. Lembaga Pemasyarakatan dalam menjalankan fungsinya sebagai wadah pembinaan bagi narapidana juga harus memperhatikan kebutuhan Warga Binaan khususnya para narapidana penyandang disabilitas, maka dalam hal ini perlunya evaluasi diri dan meningkatkan mutu dengan tentunya melibatkan narapidana penyandang disabilitas, perawatan atau dokter Lapas, serta instansi terkait seperti Puskemas ataupun Rumah Sakit Daerah untuk menunjang kesehatan bagi narapidana.

\section{Referensi}

Abdulkadir, M. (2004). Hukum dan Penelitia Hukum. PT. Citra Aditya Bakti. http://ucs.sulsellib.net//index.php?p=show_detail\&id=19356

Abdullah, R. H. (2015). URGENSI PENGGOLONGAN NARAPIDANA DALAM LEMBAGA 
PEMASYARAKATAN Urgency of Class of Prisoners in the Correctional Institution.

Fiat Justisia Jurnal IImu Hukum, 9(1).

Basri, H. (2021). Perlindungan Hukum Terhadap Pelaku Tindak Pidana Berdasarkan

Sistem Peradilan Pidana Indonesia. SIGn Jurnal Hukum, 2(2), 104-121. https://doi.org/10.37276/sjh.v2i2.90

Dewi, R. K., Pramana, R. P., Sadaly, H., Dewi, R. K., Pramana, R. P., \& Sadaly, H. (2020). Kendala Mewujudkan Pembangunan Inklusif Penyandang Disabilitas. The SMERU Research Institute.

Kaukabuddin. (2021). penegakan sanksi terhadap perusahaan tidak membayar upah pekerja di masa pandemi covid-19 ditinjau undang undang cipta kerja. Universitas 17 Agustus 1945.

Pawestri, A. (2017). 164164 There are Law Number 39 of 1999 which is supplemented by Law Number 19 of 2011. The replacement of Law Number 4 of 1997 with Law Number. 2(1). http://www.republika.co.id/berita/nasional/umu

pemasyarakatan.com. (n.d.). 10 Prinsip Pemasyarakatan. https://www.pemasyarakatan.com/sepuluh-10-prinsip-pemasyarakatan/

Pujiono, D. W. (2021). NUSANTARA: Jurnal IImu Pengetahuan Sosial PENYEDIAAN FASILITAS BAGI NARAPIDANA PENYANDANG DISABILITAS PADA LAPAS KELAS II A BEKASI 1 Dedy Wasis Pujiono. Penyediaan Fasilitas Bagi Narapidana Penyandang Disabilitas Pada Lapas Kelas II A Bekasi, 8(2), 199-203. https://doi.org/10.31604/jips.v8i2.2021.199-203

RAHARJO, A. H. (2014). Skripsi pemenuhan hak narapidana anak untuk mendapatkan pendidikan di lembaga pemasyarakatan.

Setiady, T. (2010). Pokok Hukum Penitensier. Alfabeta. http://opac.lib.unlam.ac.id/id/opac/detail.php?q1=340\&q2=Set\&q3=P\&q4=-

Soekanto, S. \& S. M. (n.d.). Penelitian Hukum Normatif (Suatu Tinjauan Singkat). In Penelitian Hukum Normatif (Suatu Tinjauan Singkat). Rajawali Pers, Jakarta.

Subarji, J. F. (2021). 24977-49744-1-PB. Pemenuhan Hak Atas Kesehatan Bagi Narapidana Disabilitas Ditinjau Dari UU No 8 Tahun 2016 Tentang Penyandang Disabilitas Dan UU No 12 Tahun 1995 Tentang Pemasyarakatan (Studi Kasus Di Lapas Kelas I Lowokwaru Malang), 7. 
Sugiono, Ilhamnudin, \& Rahmawan, A. (2014). Klasterisasi Mahasiswa Difabel Indonesia Berdasarkan Background Histories dan Studying Performance. Indonesian Journal of Disability Studies, 1(Klastering), 20-26.

Undang-Undang Republik Indonesia. (1995). Undang-Undang Republik Indonesia Nomor 12 Tahun 1995 Tentang Pemasyarakatan.

Undang-Undang Republik Indonesia. (1999). Undang-Undang RI Nomor 39 Tahun 1999 Tentang Hak Asasi Manusia.

UU No 8 Tahun 2016. (2016). Undang-Undang Republik Indonesia Nomor 8 Tahun 2016 Tentang Penyandang Disabilitas.

Winarno, S. (1982). Pengantar Penelitian IImiah. http://opacarpusdawonosobokab.perpusnas.go.id/detail-opac?id=240

Wirawan, H. F. C. (2021). NUSANTARA: Jurnal IImu Pengetahuan Sosial PEMENUHAN HAK NARAPIDANA KELOMPOK RENTAN KHUSUS DISABILITAS DI LAPAS KELAS I MADIUN 1 Hendra Fikry Cindhy Wirawan. 8 No. 3, 238-244. https://doi.org/10.31604/jips.v8i3.2021.238-244

Wulandari, S. (2012). 303-1163-1-SM. Efektifitas Sistem Pembinaan Narapidana Di Lembaga Pemasyarakatan Terhadap Tujuan Pemidanaan, 9. 